\title{
RESPONSE \\ Judaism and Christianity: \\ Reading Cardinal Koch's Address Between the Lines and Against the Grain
}

\author{
Peter C. Phan , Georgetown University
}

A Response to Cardinal Kurt Koch's October 30, 2011 Keynote Address at Seton Hall University during the $10^{\text {th }}$ Annual Meeting of the Council of Centers on Christian-Jewish Relations

In his address, Kurt Cardinal Koch delivers what he promises, namely, outlining the theological issues involved in the Jewish-Christian dialogue and attempting answers to them on the basis of biblical and magisterial teachings (with-as to be expected-abundant and approving citations from Joseph Ratzinger/Benedict XVI). Koch's treatment of these issues is strictly theological, examining them apart from their cultural and socio-political contexts, which are often the colossal elephant in the room, and from the dialogue with Islam, another gigantic elephant. It is of course legitimate to ask whether another approach would offer a more fruitful understanding of these theological issues, for instance, one that takes into account the two elephants just mentioned. However Koch's essay should not be assessed for what it does not intend to do but only for how well it does what it sets out to do, that is, to present the theological issues in the Jewish-Christian dialogue and provide answers to them from the Roman Catholic perspective. In this respect, Koch's paper is an informative and authoritative guide.

My intention here is neither to provide alternative answers to Cardinal Koch's nor to propose another set of theological issues for the Jewish-Christian dialogue. Rather, I take Koch's text at its face value and attempt to read between the lines, saying what is left unsaid, and against the grain, deconstructing what is being said to unearth the layers of the Cardinal's arguments. My brief essay is a critical gloss on rather than a run-of-the-mill full response to Cardinal Koch's presentation.

The Shoah and Christian Responsibility?

Cardinal Koch begins his lecture with reflections on "the complex history between Christians and Jews" and comments on the role of Christians in the Holocaust:

The Shoah cannot and should not however be attributed to Christianity as such: it was in fact led by a godless, anti-Christian and neo-pagan ideology.

Koch goes on to say:

Even though the primitive racist antisemitism of the Nazi ideology, which had of course developed already in the $19^{\text {th }}$ century, has nothing in common with Christianity, we Christians nevertheless have every cause to remember our complicity in the horrific developments, and above all to confess that Christian resistance to the boundless 
inhuman brutality of ideologically-based National Socialist racism did not display that vigour and clarity which one should by rights have expected.

Toward the end of his speech he says:

Because the cross of Jesus Christ has again and again in the course of Christian history been misused as an anti-sign of hostility and hatred towards the Jews by condemning them as deicides, Christians today have every reason and a strict obligation to proclaim and testify also to the Jews the cross of Jesus as a sacrament of reconciliation.

Placed side by side, these three statements strike a loud discordant note, and it is only by means of a Houdini-like verbal prestidigitation that they can escape the web of their mutual contradictions. Of course, the Shoah cannot and should not be "attributed" to Christianity, as the Cardinal contends, if by this is meant that Christianity has taught that the Jews must be exterminated from the face of the earth. To the best of my knowledge, however, no reputable historians, not even the most rabid anti-Christian and anti-Pius XII ranters and ravers, have claimed that the Christian churches were actively collaborating with Hitler in formulating the Nazi ideology and in gassing six million Jews. To argue that Christianity has nothing in common with Nazi ideology because the church never was in cahoots with it would be setting up a strawman easy to knock down. But the point is not that the church was a Nazi collaborator. Rather it is that the centurieslong history of "hostility and hatred towards Jews" committed by Christians, the existence of which Koch acknowledges, has contributed to the rise of that "godless, anti-Christian and neopagan ideology." Christians can of course do "godless, anti-Christian and neo-pagan" things, if the circumstances are right, and Christian antisemitism and anti-Judaism provided the right mix for Nazi racism.

Even if, for the sake of argument, it is conceded that "the primitive racist anti-Semitism of the Nazi ideology...has nothing in common with Christianity," can one confidently assert that Christianity has nothing to do with the antisemitism of the Nazi ideology? Is it not this history of "violence and hatred towards the Jews" that allowed most Christians, including prominent church leaders in Germany and elsewhere, Catholic and Protestant alike, to agree with, condone, keep silence, turn a blind eye, or make ineffective protests and condemnations against Nazi racism? This is not to deny that there were "righteous Gentiles," including, even according to some Jews, Pius XII. But that is not the point. The point is that virulent antisemitism and anti-Judaism runs deep in Christian veins, poisoning the very blood that is to give life to the Christian body. To make a distinction between "Christianity as such" (emphasis added) and guilty Christians, presumably small in number, in order to save the reputation of Christianity is at best a theological subterfuge, at worst living in denial, no less execrable than the excommunicated-now-reconciled Catholic Bishop Richard Williamson's denial of the Holocaust.

Perhaps Cardinal Koch puts a lot of stock on the phrase as such when he denies that the Shoah can and should be "attributed" to Christianity. This is the prototypical theological ploy to exculpate the church out of the concern to preserve its "holiness." It is the same ploy employed by some Muslims after 9/11 to say that those murderous acts should not be attributed to Islam. But the distinction is vacuous. There is no Christianity as such, to use the Cardinal's words, apart from flesh-and-blood Christians, just as there is no Islam as such without flesh-and-blood Muslims. Furthermore, the history of virulent antisemitism and anti-Judaism is an inerasable part of the church as an institution, and not simply an errant behavior of a few rotten Christians and even Christian leaders. It was deeply and widely embedded in our biblical exegesis, preaching, catechesis, theology, liturgy, and law. Not to recognize this fact and perpetuating a distinction that is unconvincing, especially to non-Christians, has the unintended effect of missing an 
opportunity to seriously examine the longstanding antisemitic and anti-Judaic heritage of Christianity and undermining that which the Cardinal wants every Christian to do, namely, "to proclaim and testify also to the Jews the cross of Jesus as a sacrament of reconciliation."

It should not scandalize any Christian to say that the church is "holy" (holiness as a gift of God) and at the same time "unholy" (holiness as a yet unfulfilled task), or to use the play of words in German, the church's holiness is both Gabe and Aufgabe. The church, as every Christian, is simul justus et peccator. It is high time that we acknowledge the responsibility of Christianity/the church as such for the Holocaust and its sins of commission as well as of omission. This confession is no masochistic breast-beating. On the contrary, it is only in this acknowledgment that we, who were not present at the Holocaust, can honestly and sincerely own it as our own deed and repent and convert and amend.

Furthermore, it is rather odd that Koch urges Christians "to proclaim and testify also to the Jews the cross of Jesus as a sacrament of reconciliation" (emphasis added). Why should the Jews be the target of this proclamation and witness of the cross as sacrament of reconciliation, especially after the Holocaust? Are not rather the Christians and Christianity as such that which must be reminded-not least by the Jews - of their shameful failure to live out the dynamic of the cross of Christ, that is, one of self-emptying and service, and not domination and ghettoization? Who needs to be reconciled and with whom? Certainly, not Jews with Christians, but rather Christians with Jews, from whom they must humbly beg forgiveness!

Not "Substitution" but "Fulfillment"?

Cardinal Koch vigorously insists that the New Testament does not "replace," "substitute," or "supersede" the so-called Old Testament. Rather the former, he says, "fulfills" the latter. This thesis is repeated with regard to the related themes of covenant and People of God. In proposing this idea the Cardinal does not of course claim to introduce a theological novelty. The nonsupersessionist motif has been a commonplace in the post-Vatican II era. Nevertheless, it is reassuring that it is now adopted not only by a large number of theologians but also by the current head of the Pontifical Council for Christian Unity (and of course his predecessor Cardinal Walter Kasper).

But is "fulfillment" reassuring to those whose covenant we claim to fulfill? What is meant by "fulfillment" that is so different from "replacement" that can prevent genocide and pogroms? Here again let us read between the lines and against the grain. The Cardinal cites with admiration Pope Benedict XVI's argument that just as after the destruction of the Second Temple in the year 70 the Pharisees developed an alternative interpretation of the Old Testament to that of the Sadducees, one without a temple, so there can now be two interpretations of the Old Testament, the Christological exegesis of the Christians and the rabbinical exegesis of Judaism:

Since both modes each involved a new interpretation of the Old Testament, the crucial question must be precisely how these two modes are related to one another.

Koch then cites, again with admiration, a statement, which he claims Benedict endorses, from the Pontifical Biblical Commission "The Jewish People and Their Sacred Scriptures in the Christian Bible":

The Jewish reading of the Bible is a possible one, in continuity with the Jewish scriptures of the Second Temple period, analogous to the Christian reading which developed in 
parallel fashion....Both readings are bound up with the vision of their respective faiths, of which the readings are the result and expression. Consequently, both are irreducible.

A few lines later, Koch goes on to say:

For the Christian faith it is axiomatic that there can only be a single covenant history of God and humanity. This is already evident in the fact that the history of God with humanity has been realized in a series of covenants, beginning with the covenant with Noah, then with Abraham, with Moses, Joshua, and Ezra, with the Prophet Jeremiah even promising a new covenant. Each of these covenants incorporates the previous covenant and interprets it in a new way. That is also true for the new covenant which for us Christians is the final covenant and therefore the definitive interpretation of what was promised by the prophets of the Old Covenant.

The Cardinal corroborates his thought on this point by citing, with approval, his predecessor Walter Kasper:

The New Covenant for Christians is not the replacement, but the fulfillment of the Old Covenant. Both stand with each other in a relationship of promise or anticipation and fulfillment.

Koch then drops his theological bombshell-bombshell, that is, for those who are familiar with the 2006 Declaration of the Congregation for the Doctrine of the Faith Dominus lesus, which was issued under the authority of the then-Cardinal Ratzinger:

If the Christian church is the fulfillment of God's plan in and with Israel, if it consists of Jews and Gentiles and if it would be "defective" without Jews, then any idea of replacement must be excluded.

Once again, we are faced with theological conundrums. First, it is disingenuous to say that there is an analogy or parallel between the way the Pharisees dealt with the Sadducees' interpretation of the Tanak on the one hand and the way Christians dealt with the rabbinical exegesis of the Tanak and the Tanak itself. Whatever disagreements there were between the Sadducees and the Pharisees, the latter never claimed to "fulfill" the former, much less the entire Tanak. Christians, on the contrary, do claim that their "New Covenant" "fulfills" the "Old Covenant" (and, for a long while, have also claimed outright replacement and supersession of the latter by the former).

Secondly, if it is said that "the Jewish reading of the Bible is a possible one," and that both the Jewish and Christian readings of the Tanak are "irreducible," what theological meaning can be assigned to "fulfillment"? Is the Christian view that the Old Testament has been "fulfilled" in the New true only for Christians, and not for others? The Cardinal's qualifying phrase "for us Christians" in his statement that "the new covenant which is for us Christians the final covenant and therefore the definitive interpretation of what is promised by the prophets of the Old Covenant" (emphasis added) seems to hint at this possibility. I however seriously doubt that Koch would subscribe to this hermeneutical "dictatorship of relativism."

But then what should we do with the Cardinal's throw-away line that Christianity is "deficient" without the Jews? This alleged "deficiency" of Christianity arises from the fact that since the Christian church is the fulfillment of God's plan in and with Israel, it consists of Jews and Gentiles and therefore would be "defective" without Jews. While Koch's intention to reject supersessionism is laudable, his argument is curious. For him, the church "consists of Jews and 
Gentiles," which is patently false. The church only consists of converted and baptized Jews and Gentiles, and not of Jews and Gentiles in general. Consequently, either the church is and will remain "deficient" until the end of time since it has had only a handful of converted Jews and there is next to no likelihood that the Jews will convert en masse to Christianity, or it is the "final covenant and therefore the definitive interpretation of what was promised by the prophets of the Old Covenant," but it cannot be both, by the Cardinal's own logic.

But is the idea of "fulfillment" really and truly respectful of the religious Other? Logically, it implies that what one has is the achievement of something lacking, desired and expected by the others, which they are unable to achieve on their own. It implies by necessity theological if not moral superiority of the Christians (or, more piously, God's work in and for us) over the religious others (and God's work in and for them). No anti-supersessionist and anti-replacement rhetoric, however eloquent, can sweeten this arrogance. Furthermore, it presupposes, dubiously, that what our religion offers is exactly what the others desire (or should desire) to have. It may however turn out that our answers, which we proclaim to be absolute, unique and universal truths, do not correspond to their questions, that our religious goal are not theirs, that our medicine is their poison. Every time I see a T-shirt or a bumper-sticker proclaiming peremptorily "JESUS IS THE ANSWER!" I am itching to ask: "Which questions? Whose questions?"

In a sense, the logic of fulfillment is easy for Christianity to adopt with regard to Judaism, since chronologically it came after Judaism, whereas it makes little sense for Judaism to claim that it is the fulfillment of Christianity. At best, it may say that it does not need Christianity to be and become what it is, or that some of its current teachings and practices may enhance those of Christianity (but not "replace" or "fulfill" them). By the same token, Christianity has been given the same, perhaps more benign, treatment by Islam, its chronological successor. Islam at least does not claim to "replace" or "fulfill" Christianity, but only to correct what it perceives as "corruptions" by Christianity. But how would Christians feel and react if they are told, especially in regions where they are a minority and have been subjected to harassments and persecutions, that their religion has been "fulfilled" by Islam? Perhaps until we Christians have walked in the shoes of the "fulfilled" and undergone the same violence and hatred like the Jews at the hands of others, we should not talk of ourselves as "fulfillers." For these and other reasons, it is high time that in the future Jewish-Christian dialogue, not only the language of "replacement," "substitution," and "supersession" but also that of "fulfillment," widely used at one time in the past, should be shelved away as outdated goods, not simply to be politically correct, but for theological reasons. Christianity can be and must try to become what Jesus wants it to be, without claiming to be the fulfillment of anyone and anything. The proof of the pudding is in the eating.

Mission to the Jews or Mission from the Jews?

In 2008, Pope Benedict introduced a change in the Good Friday prayer for the Jews in the 1962 Latin Roman Missal. The prayer reads: "That the Lord enlightens their hearts so that they may acknowledge Jesus as the Savior of all mankind" and that "as the fullness of mankind enters into the church, all Israel may be saved." Cardinal Koch argues that this prayer has been misunderstood as "a call to explicit mission to the Jews."

Citing the missionary practice of Paul and the theology of Walter Kasper, Koch says:

If one takes both sides of this delicate question [mission to the Jews] seriously, the Christian church is obligated to perceive its evangelization task in respect of the Jews, who believe in the one God, in a different manner from that to the nations. 
In what does this "different manner" consists? The Cardinal says that the Catholic Church "neither has nor supports any specific institutional mission work directed towards Jews." However this does not mean that there should be no "mission" to the Jews:

The rejection of institutional mission to the Jews does not on the other hand exclude Christians from bearing witness to their faith in Jesus Christ, but should do so in a humble and unassuming manner, particularly in view of the great tragedy of the Shoah.

Again, reading between the lines and against the grain unearths some deeply problematic positions. First, praying, and officially, in the context of liturgy, especially on Holy Friday, for the "enlightenment" by God of the "hearts" of the Jews can hardly be touted as an act of charity. (Every Christian knows why the church offers this prayer for the Jews precisely on the day commemorating the killing of Jesus.) The prayer presupposes that the hearts of the Jews in general are darkened-otherwise, why should they be enlightened? The prayer is offered for the Jews not because they are morally sinful, and hence need conversion, but because they are Jews, their religion being not separated from their ethnicity and race: their hearts are darkened, and therefore need enlightenment, because they refuse "to acknowledge Jesus as the Savior of all mankind." Would the Jews be blamed for saying to the Christians who offer that prayer: "Thanks, but no thanks. And may God not listen to your prayer!" Furthermore, would Christians who live in countries in which Muslims hold the power of life and death over them, say the same prayer, publicly, in an act of liturgical worship, substituting "Jews" with "Muslims," perhaps on a day commemorating the Crusades?

Second, is it much of a consolation to the Jews that the Vatican does not have some "specific institutional mission"-perhaps directed by a pontifical council-dedicated to the conversion of them, which, according to Koch, makes the Catholic mission to the Jews different from that to the nations? Can the Jews ignore what the ecumenical council of Florence declares in the Decree for the Jacobites in 1442: "The Holy Roman Church firmly believes, professes, and preaches that 'no one remaining outside the Catholic Church, not only pagans,' but also Jews, heretics or schismatics, can become partakers of eternal life; but they will go to the 'eternal fire prepared for the devil and his angels' (Matthew 25:41), unless before the end of their life they are received into it." In light of this solemn (infallible?) teaching on the inevitability of the Jews going to hell without entering the church, the Holy Friday prayer that "as the fullness of mankind enters into the church, all Israel may be saved" may be understood (emphasis added).

Third, a larger question may be asked: If the Catholic Church "neither has nor supports any specific institutional mission work directed towards Jews," does it mean that it has or must have institutional mission targeted for, let's say, Muslims, Hindus, and Buddhists? Even though the Cardinal does not intend to do so, his privileging the special relationship between Christianity and Judaism has the unfortunate effect of making Judaism as it were the "model minority" and undervaluing the presence of God in other religions. Dominus lesus denies that there is faith, revelation, and inspired Scripture in non-Christian religions and declares them "deficient." After the publication of the declaration, in the face of protests from some Jewish leaders, Roman officials assured them that the statement is not aimed at Judaism. But can the Jewish-Christian dialogue be hermetically sealed from the dialogue with other religions, as they are now carried out by two different curial dicasteries, without severe damages to both? Perhaps for administrative purposes, the current division of labor is to be tolerated, but theologically and pragmatically, a Christian-Jewish dialogue must not be undertaken apart from the dialogue with other religions, especially with Islam. Otherwise we would be seen as living on another planet. 
As mentioned at the beginning, my essay is not a standard "response" to Cardinal Koch's lecture. Had it been so, I would have lauded its many positive contributions. Perhaps the highest compliment that can be paid to it is that the Cardinal has gone as far as it is currently possible for an official of the Roman Curia. But it would be a serious mistake to regard what Koch has said as the outer limit for the theological conversation between Christians and Jews, much less as a canon of orthodoxy. By reading between the lines and against the grain I hope to have shown which pitfalls should be avoided in the Jewish-Christian dialogue and how its margins can be pushed wider. Above all, I hope to have shown that we need another theological language and a different context for the Jewish-Christian dialogue, for the sake of the vitality of Christianity, Judaism, and other religions, together. 